tion by more subtle means than Gramm's proposed filibuster and he will also have won friends among the antiabortion lobbyists by doing down Foster, who is a gynaecologist who has "confessed" to having carried out 37 abortions during his professional career. The injustice is literal: abortion, subject to medical investigation and approval, is still legal in the United States. Many of Clinton's early nominations were lost because those concerned had acted illegally in, for example, failing to pay taxes in respect of domestic employees, but it is cruel to lose a good nominee on the grounds that he discharged professional responsibilities within the law.

But on another disconcerting issue, Clinton must shoulder the blame more directly. At the outset of his presidency, he launched a programme called "Vaccines for Children" with the admirable goal of providing, free of charge, vaccines against the common infectious diseases of infancy. It is true that the initial rhetoric rang false; Clinton's claim that vaccine manufacturers were pursuing "profits at the expense of our children" overlooked the well-documented retreat of US pharmaceutical manufacturers from the business, to a large extent because of the high costs of legal liability suits (or of insurance against them). Nevertheless, the Congress approved the programme in 1993, believing that some 60 per cent of children in the United States would be eligible for free vaccines.

Now the General Accounting Office, an independent office working for the Congress, has produced a disturbing report on the administration of the programme. Briefly, it appears to be a hopeless muddle. Those in charge have made the mistakes that used to be common in developing countries, and have supposed that the mere existence of stocks of vaccines would ensure the immunization of children. Too little has been done to persuade parents of the benefits of vaccination, record-keeping has ranged from the non-existent to the unreliable and there are doubts that the eligibility criteria have been kept. This mess is a gift to Clinton's political opponents. Clinton would be well advised to mount a pre-emptive reform before the Republicans kill the programme altogether. Foster could tell him what to do. $\square$

\section{Brent Spar, broken spur}

Shell Oil's decision not to sink a used oil-rig at sea is a needless dereliction of rationality.

POSTERITY will bestow a strange honour on Britain's Prime Minister, Mr John Major. Last week, which is that in which he announced his resignation as leader of the government Conservative Party in order to seek re-election to that post, he also offered the House of Commons a sterling defence of the decision by the Shell Oil Company to scupper the Brent Spar, a defunct oil storage platform, in the deep Atlantic Ocean. Thus was a gambler's desperate throw juxtaposed with a piece of solid rationality. But Major earned no kudos for his courage. Shell said that it would cave in to environmental pressure almost immediately after Major had fin- ished speaking, and would arrange for the platform to be dismantled on land instead. An embattled prime minister deserves better luck than that.

Quite why Shell changed its mind is far from clear. The environmental group Greenpeace, with 500,000 members in Britain, will be eager to claim the credit. Greenpeace activists occupied the platform while it was still in place and, afterwards, when it was being towed to its last resting place. The attention paid to those events inevitably resulted in a wave of protest across Europe. The German government, which has an interest in keeping its domestic Green Party out of the arms of the Social Democrats, came out against Shell's plan even to the extent of raising the issue at the G7 summit at Halifax two weeks ago. No doubt it has also been using its influence behind the scenes in ways calculated to discomfit a multinational company such as Shell.

The irony in this episode, which has embarrassed Major, has done no credit to Shell and has again exposed the shallowness of Greenpeace's arguments on scientific issues, is that the environmental effect on deep-sea life of dumping the Brent Spar would be minimal or even beneficial. The issue, of course, is not the dumping of the platform itself, but of its contents: a substantial dollop of sludge containing 40 tonnes of oil and hundreds of kilograms of toxic heavy metals. The campaigners have been claiming that it would be irresponsible to dump this brew on the deep ocean floor, but Nisbet and Fowler suggest on page 715 of this issue that there is a different tale to tell.

Nobody suggests that the ocean floor is potentially a garbage dump of infinite capacity or that it is a barren wasteland fit for no other use: the ecology of the deep sea is as rich and varied as anything on land, and different in many fundamental ways. But, far from finding heavy-metal residues lethal or even mildly unappetizing, the bacteria of the ocean floor would have greeted the arrival of Brent Spar as if all their Christmases had come at once. Many deep-sea microbes require heavy metals as electron or energy sources in their metabolism. Ocean-floor organisms use heavy metals, hydrocarbons and brimstone because they have become adapted to quantities of these materials surging from hydrothermal vents. As Nisbet and Fowler show as an example, the Broken Spur vent field in the North Atlantic churns out up to five million tonnes of heavy metals annually, by which yardstick Brent Spar's cargo is insignificant .

What happens now? Shell will have the platform dismantled on land instead of dumping it, which must be a more hazardous process that will eventually cost the company's customers a small fortune. Greenpeace will boast of its pyrrhic victory (and its membership will no doubt increase). And, helped by the pusillanimity of governments like the German, public confusion about the circumstances in which ocean dumping can be considered safe will be increased. What matters is that the deep ocean floor is very different from the continental shelf: the problems of pollution and over-fishing in inshore waters, such as the North Sea, are very real. It is in shallow seas that human activity (and restraint) can make a difference. That is where public attention (and that of campaigners) should be directed. 